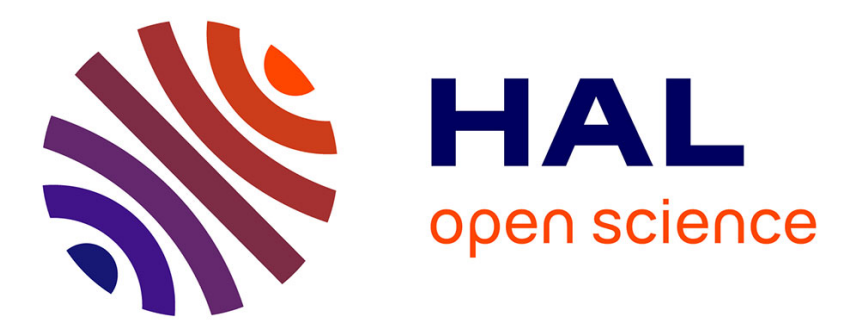

\title{
P-type SiC layers formed by VLS induced selective epitaxial growth
}

\author{
Mihai Lazar, C Jacquier, Ch Dubois, Christophe Raynaud, G Ferro, \\ Dominique Planson, Pierre Brosselard, Y Monteil
}

\section{To cite this version:}

Mihai Lazar, C Jacquier, Ch Dubois, Christophe Raynaud, G Ferro, et al.. P-type SiC layers formed by VLS induced selective epitaxial growth. European Conference on Silion Carbide and Related Materials (ECSCRM 2004), Sep 2004, Bologne, Italy. hal-02953086

\section{HAL Id: hal-02953086 \\ https://hal.science/hal-02953086}

Submitted on 29 Sep 2020

HAL is a multi-disciplinary open access archive for the deposit and dissemination of scientific research documents, whether they are published or not. The documents may come from teaching and research institutions in France or abroad, or from public or private research centers.
L'archive ouverte pluridisciplinaire HAL, est destinée au dépôt et à la diffusion de documents scientifiques de niveau recherche, publiés ou non, émanant des établissements d'enseignement et de recherche français ou étrangers, des laboratoires publics ou privés. 


\title{
P-type SiC layers formed by VLS induced selective epitaxial growth
}

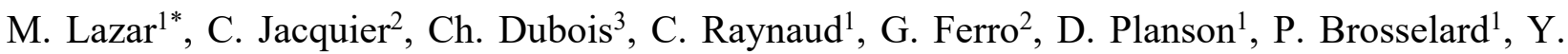 \\ Monteil ${ }^{2}$ \\ ${ }^{1}$ CEGELY(UMR CNRS 5005), Bât. L. de Vinci, INSA de Lyon, 69621 Villeurbanne Cdx France \\ ${ }^{2}$ LMI (UMR CNRS 5615) Bât. Berthollet, UCB Lyon1, 69622 Villeurbanne Cedex, France \\ ${ }^{3}$ LPM (UMR CNRS 5511) Bât. B. Pascal, INSA de Lyon, 69621 Villeurbanne Cdx France \\ *corresponding author : mihai.lazar@insa-lyon.fr, Tel +33.4.72.43.79.63, Fax +33.4.72.43.85.30
}

Unipolar SiC devices like Schottky diodes, MESFET and JFET are already or will be soon commercialized. Different universities or industrial research teams have published a non-negligible number of bipolar device demonstrators in SiC. Nevertheless large efforts were mainly targeted in increasing the breakdown voltage. Results on $19.5 \mathrm{kV}$ bipolar diodes were published [1]. In spite of that, the development of $\mathrm{SiC}$ bipolar devices is slowed down due to the low currents which are obtained in forward polarization. This is due firstly to the material quality which limits the device area and secondly to the high resistances of the $\mathrm{SiC} \mathrm{p}$-type layers and the ohmic contacts on these layers. Diminishing the $\mathrm{SiC}$ p-type layers resistance is difficult by classical process due to the solubility limit of dopants during the CVD epitaxy [2] or the material degradation by ion implantation at high doses. Partial material recovery and dopant activation are obtained after high temperature post-implantation annealing $\left(1700-1800^{\circ} \mathrm{C}\right)$. In this paper we present SiC p-type material selectively grown at relatively low temperature process by Vapour-Liquid-Solid (VLS).

The unique configuration of the VLS process, where only carbon is brought by the gas phase, allows to grow $\mathrm{SiC}$ only where the seed is covered by the Al-Si melt. Using the same procedure as in reference [3], a n-type $8^{\circ}$ off-axis $4 \mathrm{H}-\mathrm{SiC}$ substrate is covered by controlled thickness Al-Si bilayer stacking, $1 \mu \mathrm{m}$ of $\mathrm{Si}$ by $\mathrm{CVD}$ at $1000^{\circ} \mathrm{C}$ under silane followed by $2 \mu \mathrm{m}$ of $\mathrm{Al}$ deposited by sputtering. Photoresist was deposited on the sample and Al patterns are defined by photolitography and subsequent $\mathrm{Al}$ wet etching. Using the formed Al mask, RIE ( $\left.\mathrm{SF}_{6}-\mathrm{O}_{2} 250 \mathrm{~W}-60 \mathrm{mTorr}\right)$ was performed to locally remove the $\mathrm{Si}$ and $\mathrm{SiC}$ up to $4 \mu \mathrm{m}$ in the substrate

The sample as prepared is heated up to $1000^{\circ} \mathrm{C}$ in a $\mathrm{RF}$ reactor on a graphite susceptor under $5 \mathrm{slm}$ Ar. Propane is then flowed in the reactor and reacts with the Al-Si melt formed by the $\mathrm{Al} / \mathrm{Si}$ patterns. Al-doped $\mathrm{SiC}$ layers are thus grown selectively at the place where the liquid is present. Results of selective growth by VLS are presented in the figure 1. It is clear that this method enables to grow SiC layers with different size (up to $800 \mu \mathrm{m}$ ) and shape of patterns. For larger patterns, it is important to increase the $\mathrm{Al} / \mathrm{Si}$ bilayer thickness in order to avoid dewetting upon melting. Note that the initial Al/Si thickness ratio corresponds to a molar ratio of 70/30.

The Al doping concentration was determined by SIMS measurements with CAMECA IMS4F using an $\mathrm{O}^{2+}$ ion beam. The $\mathrm{Al}$ profile (figure $2 \mathrm{a}$ ) presents a very high concentration in surface (4 to $5.10^{20} \mathrm{~cm}^{-3}$ ) in the first $40 \mathrm{~nm}$ to decrease after to a plateau of $3.10^{19} \mathrm{~cm}^{-3}$ and finally to fall at the interface between the VLS layer and the substrate. This could be related to the Si content impoverishment during VLS growth as the initial amount of Si is limited. The interface is clearly showed by the evolution of ${ }^{12} \mathrm{C},{ }^{30} \mathrm{Si},{ }^{14} \mathrm{~N}$ or ${ }^{1} \mathrm{H}$ profiles: the first two increase simultaneously before to reach a constant plateau revealing a stoichiometric difference between the epitaxial VLS layer and substrate; the ${ }^{14} \mathrm{~N}$ decreases indicating a higher $\mathrm{N}$ concentration in the epitaxial VLS layer; the hydrogen profile shape follows the one of Al in the VLS layer with an overshoot at the interface. 
Electrical I-V measurements were performed on these layers, in vertical configuration (figure $3 \mathrm{a}$ ) to chuck the insulation of the epitaxial layer from the substrate, and in horizontal configuration (figure $3 b$ ) to estimate the sheet resistance of these layers. In vertical mode a rectifier behavior is found with a threshold voltage of $2 \mathrm{~V}$ in forward bias. The p-n junction is confirmed and thus the
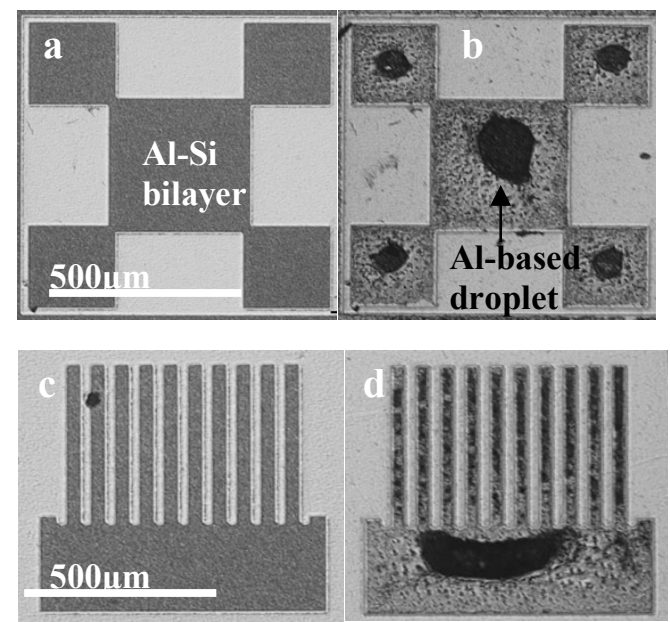

Figure 1 : illustration of the selective growth using VLS process. Figure a and c) before the growth. Figure $b$ and $d$ ) after the growth. Note the remaining Al-based droplets on the patterns. The white scale corresponds to $500 \mu \mathrm{m}$.

In the final paper the discussion will de developed on the electrical properties of the p-type $\mathrm{SiC}$ layers and its physical properties.

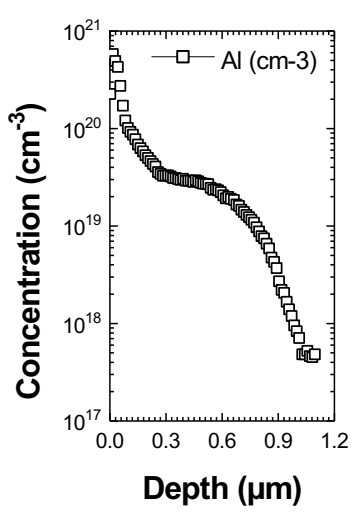

a)

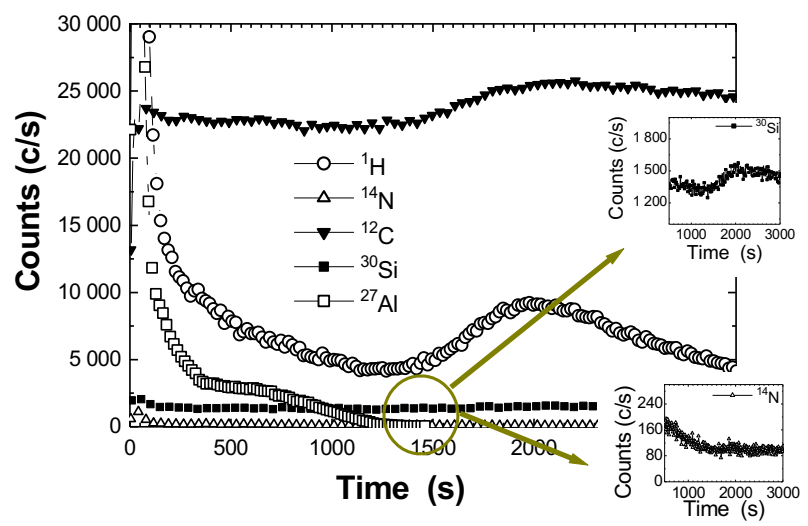

b) p-type layer may be electrically analyzed. In lateral mode the almost linear current versus voltage variation shows ohmic contact behavior between the pads (tungsten carbide) and the p-type SiC. We remark the low level of the current, which is typical for semiconductor behaviour of the p-type SiC layers. To estimate the sheet resistance of the formed p-type $\mathrm{SiC}$ layers, four - points I-V measurements were performed on Van-der-Paw structures. The sheet resistance found was $5.5 \mathrm{k} \Omega$ which represent a promising result compared to those obtained on ion implantation layers [4]. The square resistance is still high due to the $\mathrm{Al}$ concentration decrease from the surface to the interface (the calculated sheet resistance with this profile is about $3.5 \mathrm{k} \Omega$ ). On the other hand, no difficulty was encountered to take the contact thanks to the higher Al level at the surface.
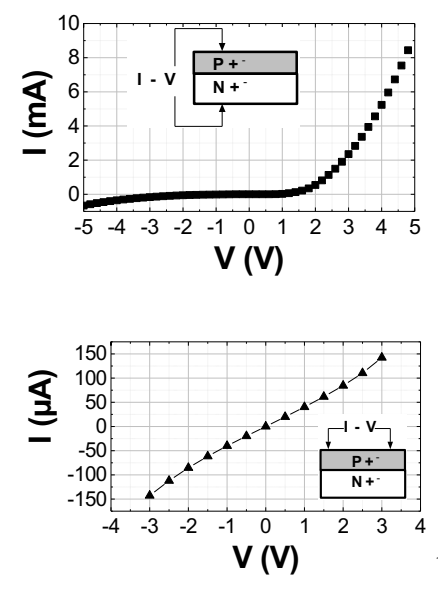

Figure 2 : (a) Al doping profile in semi-logarithmic scale, (b) SIMS spectra in linear scale with the evolution of ${ }^{12} \mathrm{C},{ }^{30} \mathrm{Si},{ }^{14} \mathrm{~N},{ }^{1} \mathrm{H}$ and ${ }^{27} \mathrm{Al}$ profiles at the interface

Figure 3: I - V measurements in vertical (a) and lateral configuration (b)

[1] Y. Sugawara, D. Takayama, K. Asano, et al., ISPSD’01, Osaka, p. 27

[2] M.K. Linnarson, P.O.A. Person, H. Bleichner et al., Mat. Sci. Forum, 2001, 353-356, p. 583-586

[3] C. Jacquier, G. Ferro, P. Godignon, J. Montserrat, O. Dezellus, Y. Monteil, To be published in Mat. Sc. Forum 04

[4] V. Heera, D. Panknin, W. Skorupa, Applied Surface Science, 2001, Vol. 184, p. 307-316 